\title{
The Role of the Accounting Information Quality in Pre- Financial Crisis Management at Palestinian Government Universities
}

Mahmoud Hany M. Dalloul, Zuraeda binti Ibrahim, Sharina Tajul Urus

To Link this Article: http://dx.doi.org/10.6007/IJARAFMS/v12-i1/11705 DOI:10.6007/IJARAFMS /v12-i1/11705

Received: 19 November 2021, Revised: 21 December 2021, Accepted: 28 December 2021

Published Online: 12 January 2022

In-Text Citation: (Dalloul et al., 2022)

To Cite this Article: Dalloul, M. H. M., Ibrahim, Z. binti, \& Urus, S. T. (2022). The Role of the Accounting Information Quality in Pre-Financial Crisis Management at Palestinian Government Universities. International Journal of Academic Research in Accounting Finance and Management Sciences, 12(1), 64-78.

Copyright: (c) 2022 The Author(s)

Published by Human Resource Management Academic Research Society (www.hrmars.com)

This article is published under the Creative Commons Attribution (CC BY 4.0) license. Anyone may reproduce, distribute, translate and create derivative works of this article (for both commercial and non-commercial purposes), subject to full attribution to the original publication and authors. The full terms of this license may be seen at: http://creativecommons.org/licences/by/4.0/legalcode

Vol. 12, No. 1, 2022, Pg. 63 - 77

Full Terms \& Conditions of access and use can be found at http://hrmars.com/index.php/pages/detail/publication-ethics 


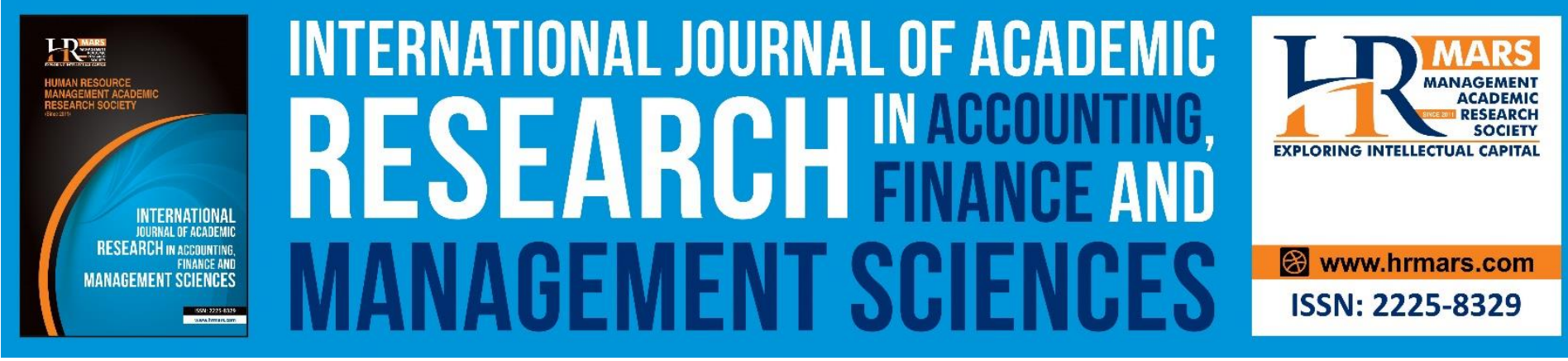

\title{
The Role of the Accounting Information Quality in Pre-Financial Crisis Management at Palestinian Government Universities
}

\author{
Mahmoud Hany M. Dalloul, Zuraeda binti Ibrahim, Sharina \\ Tajul Urus \\ Faculty of Accountancy, Universiti Teknologi Mara, Malaysia. \\ Email:mahmoooud21@gmail.com,zurae229@uitm.edu.my,sharina675@uitm.edu.my
}

\begin{abstract}
The main purpose of this study is to investigate the role of the quality of accounting information in improving the effectiveness of pre-financial crisis management. The importance of accounting information stems from reducing the state of uncertainty and increasing the level of confidence of the decision-maker, especially during critical times such as financial crises. Therefore, by understanding this role in managing financial crises, Palestinian government universities can effectively detect early signs of the financial crisis, which in turn enhances their ability to prepare for and prevent the financial crisis. In fact, this contributes to supporting the ability of these universities to create and follow a proactive strategy in facing and limiting financial crises, in which the quality of accounting information performs a crucial role. The study used the descriptive analytical method and the quantitative approach, where the manual questionnaire was adopted as a tool for data collection. The population of the study is represented by the employees of the accounting and financial departments at Al-Aqsa University, which are 40 employees, and they all constituted the sample of the study. The study relied on the Smart-PLS program (v.3.3.3) to analyze data and test hypotheses. The findings revealed a statistically significant impact of the quality of accounting information in achieving the effectiveness of pre-financial crisis management. Accordingly, the study recommended the necessity of availability and reliance on high quality accounting information for its critical and vital role in detecting early signs of the financial crisis and improving preparedness and prevention capabilities. Future research is recommended to focus on exploring the mediating and moderating factors that affect the relationship between the quality of accounting information and pre-financial crisis management.
\end{abstract}

Keywords: Accounting Information Quality, Pre-Financial Crisis Management, Palestinian Government Universities, Financial Crisis, Accounting Information.

\section{Introduction}

Our contemporary world are engulfed by various crises and disasters of various kinds, such as administrative, financial, environmental, political, economic, security and social 
MANAGEMENT SCIENCES

Vol. 12, No. 1, 2022, E-ISSN: 2225-8329 @ 2022 HRMARS

crises. This resulted from the abrupt changes took place within the internal or external environments of organizations, and even the countries. Despite the exposure of people through various crises through successive civilizations, the interest in the science of crisis management has emerged only recently. This is due to the multiplicity of crises and devastating disasters with changing forms, in addition to the scientific and development renaissance all over the world. The development and deepening of crisis management science have become an inevitable necessity for all countries, organizations and bodies alike (Mubarak, 2021).

Crises are considered important and influential events and become challenges in daily lives of individuals, organizations, society, state or government. Undoubtedly, crises have become an integral part of public life. It constitutes a source of worrying and concern for decision-makers, leaders, and citizens themselves, this concern stems from the nature of crises, as they are sudden events that are not planned in advance and require decisive and fateful decisions, in addition to successful leadership and quality information (Al-Jamal, 2021). Crises are an inevitable reality facing various institutions and organizations. The method of dealing with the crisis adopted by the organization is considered a basis for its success or failure in resolving the crises it encounters. These methods vary in the form of positive and effective solutions that enrich the organization and support its position. Additionally, passive and traditional withdrawal solutions may affect current status and stability (Abusisi, 2020). Abusisi (2020) further asserted the scenario would reflect on economic condition and sustainability hence may lead to the possibility of failure to harmonize and adapt to crises, especially the financial crisis.

Organizations of all sizes and types operate today within an environment characterized by continuous and rapid development in various economic, social and cultural fields, especially technology, with the emergence of what is known as the information revolution and digital divides between institutions and nations (Radwan, 2020). Al Laqta (2019) pointed out that the success of organizations also depends upon the creative management that enables them to curb and confront crises and disasters with an appropriate decision. Effective administrative decisions signify decisions based on a sufficient amount of information that has the characteristics of quality and accuracy. Although many studies have indicated the importance of information, including accounting and finance, there are still managers who abandon decision-making in light of crises for fear of facing those crises. Successful management requires many rational decisions, and rational decisions depend on the quality and quantity of information available. That is, access to rational decisions in crisis and disaster management requires a sophisticated information base that is efficiently managed by specialists and experts to prepare information and transfer it to decision-making centers at all levels (Radwan, 2020; Al Laqta, 2019).

The university is a source of thought, science and knowledge. It plays an important role in the development of society by providing qualified manpower capable of achieving comprehensive development. This depends on the extent to which universities are able to perform the basic function entrusted to them, which is teaching, research, and community service (Abusisi, 2020). Al-Jamal (2021) indicated Palestinian universities are experiencing stifling and exacerbating financial crises, which are part of the crises afflicting Palestinian society as a whole. The poor economic situation in general, the accumulation of financial deficits in their budgets, the lack of financial allocations provided by the government to these universities and their irregularity, the insufficient return on university tuition fees. Moreover, the continuous rise in operational and educational costs, the lack of investments and 
subjective financial returns to universities, and the scarcity of support provided to universities from the private sector and the local community have led to the deterioration of the financial situation of universities. Al-Jamal (2021) added, stressing that what exacerbated that financial crisis for Palestinian universities was the occurrence of the major global crisis due to the spread of the new Corona virus (COVID-19) back in December 2019, had a profound impact on all aspects of social life, economic and health. Nonetheless, the crisis also cast its shadows on the education sector. It prompted schools, universities and educational institutions to close their doors as a means of social distancing to reduce the chances of the virus spreading. Consequently, it also raised great concern among those affiliated with this sector in all educational institutions; In light of the crisis may protract. Abu Baker (2020) expressed that despite the procedures taken by Palestinian university administrations to confront the financial crisis, these procedures contributed to alleviating the manifestations of the crisis temporarily and they did not provide radical solutions to the financial problems. It did not prevent its return to aggravation again, in addition to the confusion it creates in the educational process and its regularity, and tension in its relationship with the student movement and its councils. This places the responsibility of university administrations on searching for radical and comprehensive solutions to the problems (Abusisi, 2020; Al-Ajrami, 2019; Al Zaanin, 2018).

In a nutshell, from the discussion above the study on the accounting information quality roles in pre-financial crisis management by the university is still nascent. This leads to the main research question on; What role does the quality of accounting information perform in the effectiveness of pre-financial crisis management in Palestinian government universities?

In an attempt to answer the research question, This study examines the role of the quality of accounting information in improving the effectiveness of pre-financial crisis management by supporting the tasks of detecting early warning signs and the tasks of preparing and preventing the financial crisis in Palestinian government universities. Thus, this study aims to investigate the quality of accounting information. In addition to determining the effectiveness of pre-financial crisis management in Palestinian government universities. Additionally, exploring tasks related to detecting early warning signs of a financial crisis. Moreover, identifying the tasks of preparedness and prevention of the financial crisis. The study also attempts to measure the relationship between the quality of accounting information systems and the effectiveness of financial crisis management. Estimating the relationship between the quality of accounting information systems and the discovery of early warning signs of the financial crisis. Assessing the relationship of the quality of accounting information systems to the preparedness and prevention of the financial crisis in Palestinian Government Universities.

The remainder of the paper is organized as follows. The next section presents the theoretical foundation and the literature review. This is followed by a framework for research and hypothesis development. Subsequently, the description of the research methodology is outlined. The result is presented in the following section. Finally, the discussion and conclusion mark the conclusion of the paper.

\section{Literature Review}

Valuable information is information that fulfills the needs and expectations of users. The quality of information is represented in the ability of information to provide a substantive impact that helps in making accurate and correct decisions by the decision maker, increasing confidence and reducing the uncertainty facing the decision-making process (DeLone \& 
MANAGEMENT SCIENCES

Vol. 12, No. 1, 2022, E-ISSN: 2225-8329 @ 2022 HRMARS

McLean, 2016; Romi, 2013). Good information has many characteristics that it must have in order to meet the desires and requirements of the beneficiaries (Sorongan \& Hidayati, 2020; A'dwan, 2019). Those characteristics for information are accuracy, understandability, availability, completeness, accessibility, relevance, suitability, reliability the format of input/output usability, timeliness, usefulness conciseness, concise representation precision currency appropriateness, interpretability, assurance content context and linkage quality transaction processing neutrality punctuality up-to-date comprehensive, organized, convenience, sincerity, believability, ease of manipulation, error free, security. objectivity and reputation (Putra \& Setiawan, 2020; Sorongan \& Hidayati, 2020; Rahi \& Abd.Ghani, 2018; Shagari, 2018; Susanto, 2017; Mkonya, Jintian \& Kyando, 2017; DeLone \& McLean, 2016; Tam \& Oliveira, 2016; Romi, 2013). Effective management before the occurrence of the financial crisis is very important as it includes many procedures and instructions that, if implemented appropriately, organizations avoid the occurrence of many crises that vary in severity from one organization to another. The tasks of the pre-financial crisis management focus on recognizing the early warning signs that warn of the possibility of an imminent financial crisis (Alpaslan \& Mitroff, 2021; Al Eid \& Arnout, 2020; Hanna, Abdul Aziz \& Najib, 2018). This is achieved through continuous monitoring of the initial signs of the crisis and an attempt to classify and analyze them as well as monitor changes in the internal and external work environment. In addition, preparations are being made to confront the financial crisis and work to prevent it, as there is adequate planning and preparation for all possible scenarios of the financial crisis by analyzing the risk factors and understanding them well. In sum, it requires the presence of a trained staff to simulate crises and identify ways to confront them (Le \& Phi, 2021; Berbekova, Uysal \& Assaf, 2021; Alpaslan \& Mitroff, 2021; Ricke, 2020; Nizamidou \& Vouzas, 2020; Kao, Wang \& Farquhar, 2020; Al Eid \& Arnout, 2020; Tokakis, Polychroniou \& Boustras, 2019). Alabaddi, Rahahleh, Muflih, Farajat, Al-Nsour and Almahameed (2020) conducted a study trying to identify the impact of system quality and information quality on crisis management and applied their study to Jordanian mobile telecommunications companies. Where data was collected through a questionnaire with the participation of 80 managers. The results showed a strong impact of the quality of information and the quality of the system on crisis management and stressed the importance of these variables. A'dwan (2019) studied the effectiveness of management information systems and their role in improving crisis management in the ministries of social development and labor in the Gaza Strip. The problem was the weak handling of crises in the two ministries, and it was not at the required level. A'dwan (2019) followed the descriptive method in his study and used the questionnaire as a research tool. He also took from all the employees in the higher centers such as the population for his study, and their number was 142 employees. One of the most important results of his study was that information systems have a significant role and impact in crisis management, and the quality of information had a strong relationship and impact in crisis management, especially pre-crisis management. The study of Hanna, Abdul Aziz and Najib (2018) came to determine the role of management information systems in crisis management at the University of Mosul. The study focused on the principals and heads of departments in some colleges, where 50 questionnaires were distributed and 44 questionnaires were collected. Their results were represented in the existence of a correlation between all elements of management information systems in the face of crisis management in all its stages. Moreover, in a study conducted by Almashaqba (2017) of the impact of management information systems on security crises in the Saudi Passports Directorate. He expressed that the passport office works in a changing work environment, 
MANAGEMENT SCIENCES

Vol. 12, No. 1, 2022, E-ISSN: 2225-8329 @ 2022 HRMARS

and this increases the possibility of crises in the absence of effective information systems. The study used the descriptive analytical method and the questionnaire as its tool. Where 135 questionnaires were randomly distributed to employees. The study found that there is a significant effect of management information systems on the management of security crises. Zwyalif (2015) conducted a study on the success of accounting information systems and their impact on the stages of crisis management in Jordanian commercial banks. Zwyalif (2015) said that banks faced difficulties in managing their financial resources due to the global financial crisis, the decline in the value of their shares and investments, and the inability of borrowers to repay their debts. To achieve the objectives of her study, she used the descriptive analytical method and the questionnaire to collect data. Moreover, as residents of its study, the employees were taken into higher positions, as they numbered 146 employees. Zwyalif (2015) pointed to several results, including the presence of a significant impact of accounting information systems in the stages of crisis management. There is an impact of information quality in detecting warning signals, preparing for and preventing a crisis. In the meantime, Nour Al-Daem (2015) conducted his applied study in a Sudanese sugar factory to understand the impact of management information systems on crisis management. The problem he discussed was the lack of interest in management information systems in crisis management, which negatively affected the continuity of work in the organization and its ability to compete. The study was also applied through the descriptive analytical method and by using a questionnaire, and all employees at the higher administrative levels were considered as the population of the study. Where he distributed 120 questionnaire and retrieved 108 questionnaire. Nour Al-Daem (2015) reached a set of results, including the presence of a significant impact of administrative information systems in all stages of crisis management, and the quality of information had the effect of pre-crisis management stages.

Based on the foregoing from a review of previous literature, a framework for this study can be formed and research hypotheses are put forward as follows:

H1: Ceteris paribus, there is a positive relationship between the quality of accounting information and pre-financial crisis management.

H2: Ceteris paribus, there is a positive relationship between the quality of accounting information and detection of early warning of the financial crisis.

H3: Ceteris paribus, there is a positive relationship between the quality of accounting information and the preparation/prevention of the financial crisis.

\section{Research Framework}

This study focuses on the role of the quality of accounting information in the management of the pre-financial crisis in the Palestinian public universities. Therefore, Figure 1 shows the framework of this study, which was developed in light of previous studies such as (Alabaddi et al., 2020; A'dwan, 2019; Najib, 2018; Almashaqba, 2017). DeLone and McLean (2003) model for the success of information systems, and Mitroff (1994) model for crisis management. The framework shows that the quality of accounting information has an impact on pre-financial crisis management. The framework also clarifies the impact of the quality of accounting information on tasks related to detecting early warning signs of a financial crisis and tasks related to preparing and preventing a financial crisis. 


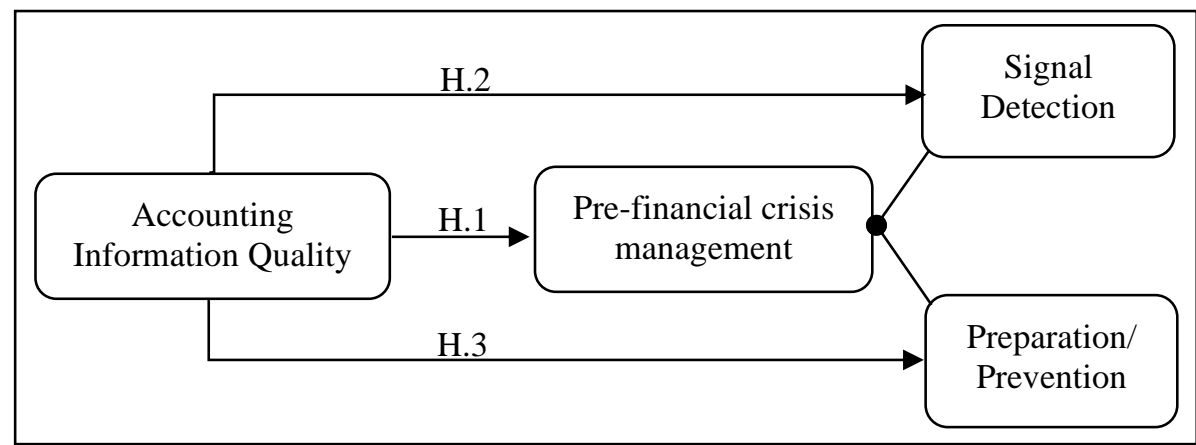

Figure 1. Framework (AIQ-PRE.FCM)

\section{Research Material and Method}

This study mainly attempts to discuss the role that the quality of accounting information plays in improving the management of the pre-financial crisis in the Palestinian government universities. To achieve this, the study began by preparing the introduction, defining the research problem, the research objective, conducting a literature review and previous studies, and developing hypotheses and a framework. In order to conduct the practical study by conducting a survey using the questionnaire, following the quantitative method. where the study targeted, as the population, Al-Aqsa University, the largest Palestinian government university, where its inception was in 1955, and the university currently includes ten faculties, the number of its students is about 22,240 male and female, and the university also includes 564 members A teaching staff, and 560 administrative employees (Al-Aqsa University, 2019). The study sample represented all employees of the Accounting and Finance Department, where 40 questionnaires were distributed and 32 questionnaires were valid for statistical analysis, with a response rate of $80 \%$. The data collection tool (the questionnaire) consists of three parts, as the first part is related to the quality of accounting information, the second part is related to pre-financial crisis management, and finally the third part is related to the characteristics of the respondents. The five-point Likert scale was used to interpret the respondents' responses to the questionnaire items.

Whereas, the quality of accounting information represents the independent variable, and the pre-financial crisis management represents the dependent variable. To measure the independent variable, the following measures were used: comparability, accuracy, completeness, verifiability, understandability, format, relevance, timeliness and predictability. While to measure the dependent variable, the following measures were used: organizational support, organizational culture, control and monitoring, planning, instructions and regulations, training, information, coordination, communication and cooperation, information systems, participation, databases, work teams, analysis, experiences.

Descriptive statistics are used to understand the characteristics of variables and the demographic characteristics of respondents. SmartPLS (v. 3.3.3) is relied on to perform many tests, including assessment of measurement model, instrument quality, validity of structures, and reliability, as well as assessment of structural model, path analysis, and hypothesis testing.

\section{Findings and Analysis}

Demographic Information

Looking at Table 1, it appears find that $56.3 \%$ of the respondents hold a bachelor's degree and $34.4 \%$ hold a master's degree, while the percentage of doctoral degree holders 
MANAGEMENT SCIENCES

Vol. 12, No. 1, 2022, E-ISSN: 2225-8329 @ 2022 HRMARS

was $9.4 \%$, in contrast, the percentage of diploma holders was $0 \%$. This indicates that most of the respondents have university and higher scientific qualifications, which reflects the level of awareness, good knowledge and their ability to give an objective and accurate response. Likewise, $59.4 \%$ of the respondents are from the accounting major, and $18.8 \%$ are from the management major, while the ratios are $9.4 \%, 6.3 \%$ and $6.3 \%$ for the economics, finance, banking and finance majors, respectively. This indicates that the respondents have scientific specializations that qualify them to answer the survey paragraphs. As most of them are from the accounting major who have sufficient knowledge and awareness of the subject of the research. Respondents with experience from 5 years to less than 10 years came first with a percentage of $40.6 \%$, followed by those with experience from 10 years to less than 15 years, then $12.5 \%$ for each of the experience less than 5 years and the experience of 15 and more. This indicates that most respondents are experienced in their work, which increases the reliability of their response on the research topic. As for the respondents' access to crisis management courses, most of them have obtained training courses in this field. The same applies to their access to training courses in the field of accounting information systems. This indicates the respondents' interest in the areas of crisis management and accounting information systems, and their awareness of the importance of obtaining adequate training in both areas. On the other hand, there were significant percentages that did not receive any training, which may indicate a weak interest of the institution in developing the skills of its employees.

Table 1. Characteristics of the sample

\begin{tabular}{|c|c|c|}
\hline Demographic characteristics & Frequency & Percentage \\
\hline \multicolumn{3}{|l|}{ Qualification } \\
\hline Diploma degree & 0 & 0.00 \\
\hline Bachelor's degree & 18 & 56.3 \\
\hline Master's degree & 11 & 34.4 \\
\hline PhD degree & 3 & 9.4 \\
\hline \multicolumn{3}{|l|}{ Specialization } \\
\hline Accounting & 19 & 59.4 \\
\hline Finance & 2 & 6.3 \\
\hline Management & 6 & 18.8 \\
\hline Economics & 3 & 9.4 \\
\hline Financial \& banking & 2 & 6.3 \\
\hline \multicolumn{3}{|l|}{ Experience } \\
\hline Less than 5 YRS & 4 & 12.5 \\
\hline 5 YRS \& less than 10 YRS & 13 & 40.6 \\
\hline 10 YRS \& less than 15 YRS & 11 & 34.4 \\
\hline 15 YRS \& over & 4 & 12.50 \\
\hline \multicolumn{3}{|l|}{ Training courses in $\mathrm{CM}$} \\
\hline None & 11 & 34.4 \\
\hline $1-3$ courses & 16 & 50.00 \\
\hline 4-5 courses & 2 & 6.3 \\
\hline More than 5 courses & 3 & 9.4 \\
\hline \multicolumn{3}{|l|}{ Training courses in AIS } \\
\hline None & 15 & 46.9 \\
\hline $1-3$ courses & 13 & .407 \\
\hline 4-5 courses & 2 & 6.3 \\
\hline More than 5 courses & 2 & 6.3 \\
\hline
\end{tabular}


MANAGEMENT SCIENCES

Vol. 12, No. 1, 2022, E-ISSN: 2225-8329 @ 2022 HRMARS

Descriptive Statistics and Analysis

Table 2 shows the results of the descriptive analysis of the variables, which includes the arithmetic mean and standard deviation. Where it appears that the quality of the accounting information came with a mean of 4.048 and a standard deviation of 0.279 , and the preparedness and prevention came with an arithmetic mean of 3.949 and a standard deviation of 0.386. In addition, the pre-financial crisis management came with an arithmetic mean of 3.881 and a standard deviation of 0.408 , while the detection of signs got an arithmetic mean of 3.723 and a standard deviation of 0.575 . Through this, it is possible to indicate the high degree of approval of respondents on the variables, which confirms the importance of the role of accounting information in the institution's ability to effectively manage its financial crisis.

Table 2. Descriptive statistic of variables

\begin{tabular}{|l|c|c|}
\hline \multicolumn{1}{|c|}{ variables } & Mean & Std. Deviation \\
\hline Accounting Information Quality (AIQ) & 4.048 & 0.279 \\
\hline Pre-financial crisis management (PRE.FCM) & 3.881 & 0.408 \\
\hline Signal Detection (S.D.) & 3.723 & 0.575 \\
\hline Preparation/Prevention (P.P.) & 3.949 & 0.386 \\
\hline
\end{tabular}

Normality Test

Through Table 3, shows the results of skewness and kurtosis of the variables. According to George and Mallery (2020) kurtosis and skewness value between \pm 1 is considered excellent, but a value between \pm 2 is also acceptable. Abuzuhri (2018) mentioned that the skewness threshold should be in the range \pm 2 and the kurtosis threshold should fall within \pm 7 (Weiber \& Mühlhaus, 2014). Based on the rule of thumb that skewness $>3$ and kurtosis $>10$ represent extreme non-normality (Abdi, Vinzi, Russolillo, Saporta \& Trinchera, 2016). Accordingly, the data follow a normal distribution as the skewness and kurtosis values of the variables fall within the acceptable threshold.

Table 3. Normality Test for variables

\begin{tabular}{|l|c|c|c|c|}
\hline \multirow{2}{*}{ variables } & \multicolumn{2}{|c|}{ Skewness } & \multicolumn{2}{c|}{ Kurtosis } \\
\cline { 2 - 5 } & Statistic & $\begin{array}{c}\text { Std. } \\
\text { Error }\end{array}$ & Statistic & $\begin{array}{c}\text { Std. } \\
\text { Error }\end{array}$ \\
\hline Accounting Information Quality (AIQ) & -0.731 & 0.414 & 1.177 & 0.809 \\
\hline Pre-financial crisis management (PRE.FCM) & -0.660 & 0.414 & 0.283 & 0.809 \\
\hline Signal Detection (S.D.) & -0.601 & 0.414 & -0.636 & 0.809 \\
\hline Preparation/Prevention (P.P.) & -0.510 & 0.414 & 0.565 & 0.809 \\
\hline
\end{tabular}

Reliability and Validity Analysis

The study used the PLS-SEM algorithm to assess the reliability of the items through the result of loading each item. As loading elements in the range 0.4-0.7 can be omitted if doing so would increase reliability, the factor loading of 0.50 and above reflects an acceptable and valid model (Hair, Hult, Ringle \& Sarstedt, 2017; George \& Mallery, 2020). It is shown in Table 4 that the loading values for all components are above 0.6 .

Cronbach's alpha coefficient and composite reliability coefficient are the most widely used methods for assessing the reliability of internal consistency, as reliability values less than 0.6 are considered poor, 0.7 is acceptable, and those above 0.8 are considered good (Pallant, 
INTERNATIONAL JOURNAL OF ACADEMIC RESEARCH IN ACCOUNTING, FINANCE AND MANAGEMENT SCIENCES

Vol. 12, No. 1, 2022, E-ISSN: 2225-8329 @ 2022 HRMARS

2016; Hair et al., 2017; Sekaran \& Bougie, 2016; Hair, Black, Babin \& Anderson, 2014). It is shown in Table 4 that the reliability values are above 0.6 .

To confirm convergent validity the most commonly used measure is the average variance extracted (AVE). Acceptable convergent validity values are considered to be the average of the extracted variance value greater than 0.5 (Hair et al., 2017; Abdi et al., 2016; Hair et al., 2014; Weiber \& Mühlhaus, 2014). Table 4 shows that the AVE values are above 0.5 .

Discriminative validity is the level at which a variable differs from its corresponding variables. It is measured by comparing the correlations of the latent structures with the square root of AVE (Hair et al., 2017; Abdi et al., 2016; Sekaran \& Bougie, 2016; Hair et al., 2014). Table 4 shows that all AVE values are greater than the correlations between latent constructs, indicating sufficient discriminant validity.

Table 4. Variables Reliability, Validity and Factor Loading

\begin{tabular}{|c|c|c|c|c|}
\hline variables & $\begin{array}{l}\text { Factor } \\
\text { Loading }\end{array}$ & $\begin{array}{c}\text { Cronbach's } \\
\text { Alpha }\end{array}$ & $\begin{array}{l}\text { Composite } \\
\text { Reliability }\end{array}$ & $\begin{array}{c}\text { Average } \\
\text { Variance } \\
\text { Extracted (AVE) }\end{array}$ \\
\hline Accounting Information Quality (AIQ) & & 0.833 & & 0.747 \\
\hline 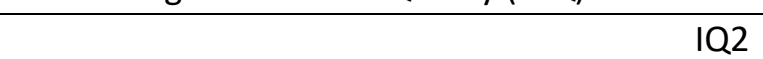 & 0.844 & & 0.898 & \\
\hline IQ3 & 0.802 & & & \\
\hline IQ4 & 0.883 & & & \\
\hline IQ6 & 0.857 & & & \\
\hline IQ7 & 0.830 & & & \\
\hline IQ9 & 0.851 & & & \\
\hline Pre-financial crisis management (PRE.FCM) & & 0.853 & 0.931 & 0.872 \\
\hline Pre11 & 0.938 & & & \\
\hline Pre14 & 0.898 & & & \\
\hline Pre24 & 0.885 & & & \\
\hline Pre29 & 0.929 & & & \\
\hline Signal Detection (S.D.) & & 0.860 & 0.912 & 0.776 \\
\hline Pre11 & 0.893 & & & \\
\hline Pre12 & 0.918 & & & \\
\hline Pre14 & 0.829 & & & \\
\hline Pre15 & 0.800 & & & \\
\hline Preparation/Prevention (P.P.) & & 0.906 & 0.932 & 0.775 \\
\hline Pre16 & 0.881 & & & \\
\hline Pre18 & 0.815 & & & \\
\hline Pre21 & 0.873 & & & \\
\hline Pre24 & 0.833 & & & \\
\hline Pre26 & 0.911 & & & \\
\hline Pre29 & 0.854 & & & \\
\hline Discriminant validit & y by Forne & -Larcker criteri & & \\
\hline & $(A \mid Q)$ & (PRE.FCI & (S.D.) & (P.P.) \\
\hline Accounting Information Quality (AIQ) & 0.864 & & & \\
\hline Pre-financial crisis management (PRE.FCM) & 0.836 & 0.934 & & \\
\hline Signal Detection (S.D.) & 0.769 & 0.873 & 0.881 & \\
\hline Preparation/Prevention (P.P.) & 0.665 & 0.826 & 0.759 & 0.880 \\
\hline
\end{tabular}


MANAGEMENT SCIENCES

Vol. 12 , No. 1, 2022, E-ISSN: 2225-8329 @ 2022 HRMARS

\section{Results of Hypotheses Testing}

Path analysis and bootstrapping technique are used in the current research to determine the nature of the relationship between the independent variables and the dependent variable. According to Table 5 that shows the results of hypothesis testing with respect to hypothesis $(\mathrm{H} 1)$, the result indicates a positive and meaningful relationship between accounting information quality (AIQ) and pre-financial crisis management (PRE.FCM) $(t=18.059, p=0.000)$. The results also showed with regard to hypothesis $(H 2)$ that there is a positive and meaningful relationship between the quality of accounting information and the discovery of early warning signs of a financial crisis (S.D.) ( $t=17.969, p=0.000)$. Moreover the results indicated with regard to hypothesis $(\mathrm{H} 3)$ that there is significant positive relationship between the quality of accounting information and the preparedness and prevention of the financial crisis (P.P.) $(t=7.674, p=0.000)$.

Table 5. Results of hypotheses testing

\begin{tabular}{|c|l|l|l|l|l|l|}
\hline Hypothesis & Path & Std. Beta & Std. Error & t-value & p-value & Decision \\
\hline H1 & AlQ -> PRE.FCM & 0.836 & 0.046 & 18.059 & $0.000^{*}$ & Supported \\
\hline H2 & AIQ -> S.D. & 0.773 & 0.043 & 17.969 & $0.000^{*}$ & Supported \\
\hline H3 & AIQ -> P.P. & 0.661 & 0.086 & 7.674 & $0.000^{*}$ & Supported \\
\hline
\end{tabular}

Note: *Significant at 0.05 (2-tailed). Note: AIQ=Accounting Information Quality, PRE.FCM=Pre-financial crisis management, S.D.=Signal Detection, P.P.= Preparation/Prevention

The value of R2 (coefficient of determination) represents the extent of variation in the endogenous latent variables that can be characterized by one or more exogenous latent variables. It indicates the total variance in the construct explained in the model (Abdi et al., 2016; George \& Mallery, 2020; Hair et al., 2014). Falk and Miller (1992) set the threshold value for R-squared as 0.10, which is the lowest acceptable level. An R2 value of 0.26 indicates a substantial value, 0.13 a moderate value, and 0.02 a weak value (Cohen, 1988). As for Chin (1998), the R2 value above 0.67 is a substantial value, above 0.33 is a moderate value, and above 0.19 is a weak value (Kassem, Khoiry \& Noraini, 2020; Omoga, 2019). In general R2 values of $0.75,0.50$, or 0.25 for the endogenous construct can be described as respectively substantial, moderate, and weak (Hair et al., 2017). Looking at the R2 values in Table 5, the quality of accounting information (AIQ) explains $69.8 \%$ of the variance in pre-financial crisis management (PRE.FCM). It also explains $59.7 \%$ of the variance in signal detection (S.D.). Moreover, explains $43.7 \%$ of the variance in preparedness and prevention (P.P.). Specifically, the results showed that the R2 values of the endogenous variables are; for PRE.FCM (0.698), S.D. (0.597) and P.P. (0.437) these are acceptable values, indicating that the model has great predictive validity.

Table 6. $R^{2}$ of Endogenous Latent Variables

\begin{tabular}{|l|c|l|l|l|l|}
\hline \multirow{2}{*}{ Latent Variables } & \multirow{2}{*}{\begin{tabular}{c} 
Variance \\
Explained \\
\cline { 3 - 6 }
\end{tabular}} & $\begin{array}{c}\text { Falk \& Miller } \\
\left(\mathrm{R}^{2}\right)\end{array}$ & \multicolumn{1}{|c|}{ Criterion for describing the result } \\
\hline $\begin{array}{l}\text { Pre-financial crisis } \\
\text { management (PRE.FCM) }\end{array}$ & 0.698 & Acceptable & Substantial & Substantial & Moderate \\
\hline Signal Detection (S.D.) & 0.597 & Acceptable & Substantial & Moderate & Moderate \\
\hline Preparation/Prevention (P.P.) & 0.437 & Acceptable & Substantial & Moderate & Weak \\
\hline
\end{tabular}


MANAGEMENT SCIENCES

Vol. 12 , No. 1, 2022, E-ISSN: 2225-8329 @ 2022 HRMARS

\section{Discussion and Conclusion}

The main purpose of this study is to determine the role played by the quality of accounting information in the management of pre-financial crises in Palestinian government universities, due to the successive financial crises faced by these universities for many different reasons. Al-Aqsa University was chosen as a case study, as it is the largest government university operating in Palestine. The focus was on employees in the Finance and Accounting Department, where 32 employees who had experience, qualifications and adequate training related to accounting information systems and financial crisis management participated by answering the questionnaire paragraphs to provide their opinion on whether the quality of accounting information would improve the ability of government universities to manage before their financial crisis. By further improving the detection of early warning signs of the possibility of a financial crisis. As well as enhancing preparedness for the financial crisis, good planning for it and an attempt to prevent it before it occurs. The practical investigation showed that there is a high approval of respondents on the paragraphs and variables of the survey, and this indicates the critical importance of high-quality accounting information in the pre-financial crisis management. As effective pre-crisis management depends on the presence of high-quality financial and accounting information, both in support of the tasks of discovering early warning signals or in support of preparedness and prevention tasks.

These conclusions confirmed the existence of a positive, statistically significant relationship between the quality of accounting information and the management of prefinancial crises. Moreover, there is a positive, statistically significant relationship between the quality of accounting information and the detection of early warning signs of the financial crisis. In addition, there is a positive, statistically significant relationship between the quality of accounting information and preparedness and prevention of the financial crisis. These results are in agreement with previous studies such as (Alabaddi et al., 2020; A'dwan, 2019; Hanna, Abdul Aziz and Najib, 2018; Almashaqba, 2017). This indicates the need to provide accounting information that has quality characteristics, as this will have benefits on the ability of universities to manage the pre-financial crisis with high efficiency. Therefore, it is very important for universities to have advanced accounting information systems of high quality. This study is considered one of the first studies that dealt with this topic of research in light of the scarcity of sources. As most of the previous studies focused on studying management information systems and there was no focus on managing financial crises. Therefore, we recommend that there be more studies on the quality of accounting information systems and the management of financial crises in various business sectors, whether governmental or private.

\section{References}

Abdi, H., Vinzi, V. E., Russolillo, G., Saporta, G., \& Trinchera, L. (2016). The Multiple Facets of Partial Least Squares and Related Methods. Paris: Springer International Publishing.

Abu Baker, F. (2020). The financial consequences of "Corona" on Palestinian universities. Palestine: The Palestinian Center for Policy Research and Strategic Studies-MASARAT.

Abusisi, A. G. (2020). Positive Thinking and Emotional Regulation and Their Relationship to Crisis Management Ability among University Students. Master Thesis. Gaza, Palestine: The Islamic University of Gaza. 
MANAGEMENT SCIENCES

Vol. 12, No. 1, 2022, E-ISSN: 2225-8329 ๔ 2022 HRMARS

Abuzuhri, N. M. (2018). Relationship between Entrepreneurship Education, Entrepreneurial Opportunity Recognition and Entrepreneurial Career Option among Palestinian Undergraduate Students. PhD Thesis. Kedah, Malaysia: Universiti Utara Malaysia.

A'dwan, M. S. (2019). The Effectiveness of Management Information Systems and its role in improving Crisis Management: Empirical study in Ministries of Social Development and Labor in Gaza Strip. Master Thesis. Gaza, Palestine: Al-Azhar University-Gaza.

Al Eid, N. A., \& Arnout, B. A. (2020). Crisis and disaster management in the light of the Islamic approach: COVID-19 pandemic crisis as a model (a qualitative study using the grounded theory). Journal of Public Affairs, 20(4), 1-14.

Al Laqta, M. A. (2019). The Effect of Techno Information Management Strategy on the Process of Making Decision in Crisis and Disasters Cases. (Status of Operation the Social Development Ministry). Master Thesis. Gaza, Palestine: The Islamic University of Gaza.

Al Zaanin, G. (2018). The dimensions of the financial crisis in Palestinian public universities. Palestine: The Palestinian Center for Policy Research and Strategic Studies-Masarat.

Alabaddi, Z. A., Rahahleh, A. H., Muflih, M. A., Farajat, J. M., Al-Nsour, S. N., \& Almahameed, M. A. (2020). Effect Of System Quality and Information Quality on Crisis Management An Empirical Study on Jordanian Mobile Telecommunications Companies. European Journal of Business and Management, 12(1), 73-83.

Al-Ajrami, A. A. (2019). Relationship of Organizational Structure Design with Crisis Management "Field Study on the Palestinian Universities in Gaza Governorates". Master Thesis. Gaza, Palestine: Al-Azhar University-Gaza.

Al-Aqsa University. (2019). Overview. Retrieved from

https://alaqsa.edu.ps/en/page/2770/Alaqsa-University-Gaza-Overview: https://alaqsa.edu.ps

Al-Jamal, M. M. (2021). Crises Management at Higher Education Institutions in the Gaza Strip During the COVID19 Pandemic: The Islamic University of Gaza as a Study Case. Master Thesis. Gaza, Palestine: The Islamic University of Gaza.

Almashaqba, Z. M. (2017). The impact of management information systems on the security crisis management "A study on the General Directorate of Passports in Riyadh-KSA". International Journal of Business and Management Review, 5(6), 26-47.

Alpaslan, C. M., \& Mitroff, I. I. (2021). Exploring the moral foundations of crisis management. Technological Forecasting and Social Change, 167, 120713.

Berbekova, A., Uysal, M., \& Assaf, A. G. (2021). A thematic analysis of crisis management in tourism: A theoretical perspective. Tourism Management, 86, 104342.

Chin, W. W. (1998). The Partial Least Squares Approach to Structural Equation Modeling. In G. A. Marcoulides, Modern methods for business research (pp. 295-336). New York: Lawrence Erlbaum Associates.

Cohen, J. (1988). Statistical Power Analysis for the Behavioral Sciences. New York, US: Lawrence Erlbaum Associates.

DeLone, W. H., \& McLean, E. R. (2003). The DeLone and McLean model of information systems success: A ten-year update. Journal of Management Information Systems, 19(4), 9-30.

DeLone, W. H., \& McLean, E. R. (2016). Information systems success measurement. Foundations and Trends in Information Systems, 2(1), 1-116.

Falk, R. F., \& Miller, N. B. (1992). A Primer for Soft Modeling. Ohio: The University of Akron Press.

George, D., \& Mallery, P. (2020). IBM SPSS Statistics 26 Step by Step A Simple Guide and Reference (sixteenth edition). New York: Routledge. 
MANAGEMENT SCIENCES

Vol. 12, No. 1, 2022, E-ISSN: 2225-8329 ๔ 2022 HRMARS

Hair, J. F., Black, W. C., Babin, B. J., \& Anderson, R. E. (2014). Multivariate Data Analysis. Harlow: Pearson Education Limited .

Hair, J. F., Hult, G. T., Ringle, C. M., \& Sarstedt, M. (2017). A Primer on Partial Least Squares Structural Equation Modeling (PLS-SEM) (Second Edition). USA: SAGE Publications.

Hanna, R. D., Abdul Aziz, S. K., \& Najib, S. H. (2018). The role of management information system in crisis management an empirical study in some faculties of the university of Mosul. Journal of Kirkuk University for Administrative and Economic Sciences, 8(2), 115140.

Kao, G. H.-Y., Wang, S. W., \& Farquhar, J. D. (2020). Modeling airline crisis management capability: Brand attitude, brand credibility and intention. Journal of Air Transport Management, 89, 101894.

Kassem, M. A., Khoiry, M. A., \& Hamzah, N. (2020). Assessment of the effect of external risk factors on the success of an oil and gas construction project. Engineering, Construction and Architectural Management, 27(9), 2767-2793.

Le, D., \& Phi, G. (2021). Strategic responses of the hotel sector to COVID-19: Toward a refined pandemic crisis management framework. International Journal of Hospitality Management, 94, 102808.

Mitroff, I. I. (1994). The Role of Computers and Decision Aids in Crisis Management: A Developer's Report. Journal of contingencies and crisis management, 2(2), 73-84.

Mkonya, V. L., Jintian, Y., \& Kyando, N. (2017). Effect of Using Accounting Information System on Accounting Information Quality for Projects. Proceedings of the 14th International Conference on Innovation \& Management (pp. 525-529). Wuhan, China: Wuhan University of Technology Press.

Mubarak, R. A. (2021). Crises Management Challenges and Effects on Economical Sustainable Development in Media Organizations (Al-Aqsa Media Network) 'Case Study'. Master Thesis. Gaza, Palestine: The Islamic University of Gaza.

Nizamidou, C., \& Vouzas, F. (2020). The contribution of preoccupation with failure to TQM, crisis management and HR aiming to overcome crises. The TQM Journal, 32(6), 10771098.

Nour Al-Daem, A.-S. M.-G. (2015). The effect of management information systems on crises management by applying to Asalaya Sugar Factory. White Nile Journal for studies and scientific research(6), 1-25.

Omoga, C. O. (2019). Integrated E-Marketing Adoption Model for Small Businesses. International Journal of Advanced Research in Computer and Communication Engineering, 8(5), 241-248.

Pallant, J. (2016). SPSS survival manual: A step by step guide to data analysis using IBM SPSS (sixth edition). Australia: Allen \& Unwin.

Putra, W. E., \& Setiawan, D. (2020). The success analysis of implementation of the electronic system integrated final project of Jambi University students with Delone and Mclean model approach. JEBI (Jurnal Ekonomi dan Bisnis Islam), 4(2), 147-154.

Radwan, R. A. (2020). Requirements of Strategic Vigilance and its Relation with Crisis is Management (Applied Study on Intermediate Community Colleges in Southern Governorates of Palestine). Master Thesis. Gaza, Palestine: The Islamic University of Gaza.

Rahi, S., \& Abd.Ghani, M. (2019). Integration of DeLone and McLean and self-determination theory in internet banking continuance intention context. International Journal of Accounting \& Information Management, 27(3), 512-528. 
MANAGEMENT SCIENCES

Vol. 12 , No. 1, 2022, E-ISSN: 2225-8329 @ 2022 HRMARS

Ricke, M. L. (2020). Did You Take Care of Everybody? Insights on Crisis Management from Senior Student Affairs Professionals. PhD Thesis. Greeley, Colorado, United States: University of Northern Colorado.

Romi, I. M. (2013). Testing Delone and Mclean's Model in Financial Institutions. American Academic \& Scholarly Research Journal, 5(3), 121-129.

Sekaran, U., \& Bougie, R. (2016). Research Methods For Business: A Skill Building Approach (Seventh Edition). Chichester: John Wiley \& Sons Ltd.

Shagari, S. L. (2018). Determinants of accounting information technology usage in Nigerian banking sector. PhD Thesis. Kedah, Malaylia: Universiti Utara Malaylia.

Sorongan, E., \& Hidayati, Q. (2020). Evaluation of Implementation E-Government with Delone and Mclean. INTENSIF: Jurnal IImiah Penelitian dan Penerapan Teknologi Sistem Informasi, 4(1), 22-37.

Susanto, A. (2017). How the Quality of Accounting Information System Impact on Accounting Information Quality (Research on Higher Education in Bandung). Journal of Engineering and Applied Sciences, 12(14), 3672-3677.

Tam, C., \& Oliveira, T. (2016). Understanding the impact of $m$-banking on individual performance: DeLone \& McLean and TTF perspective. Computers in Human Behavior, 61, 233-244.

Tokakis, V., Polychroniou, P., \& Boustras, G. (2019). Crisis management in public administration: The three phases model for safety incidents. Safety Science, 113, 37-43.

Weiber, R., \& Mühlhaus, D. (2014). Structural Equation Modeling: An application-oriented introduction to causal analysis using AMOS, SmartPLS and SPSS. Germany: Springer Gabler.

Zwyalif, I. M. (2015). Success of Accounting Information Systems and Their Impact on the Stages of Crises Management. Dirasat, administrative sciences, 42(1), 247-266. 